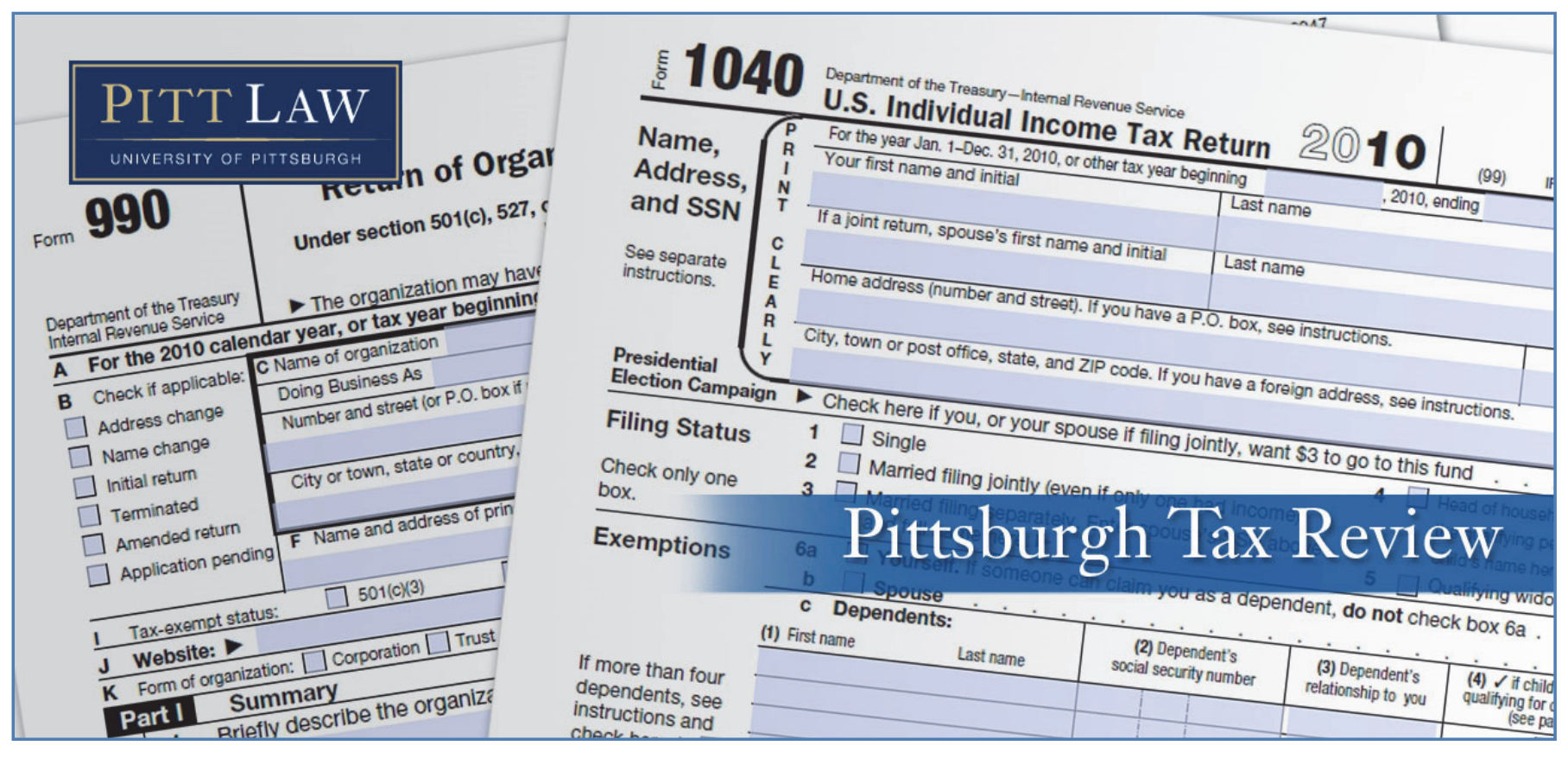

Volume 16 (2019) | ISSN 1932-1821 (print) 1932-1996 (online)

DOI 10.5195/taxreview.2019.100 | http://taxreview.law.pitt.edu

\title{
CONGRESS SHOULD HAVE AN INTEREST IN THIS INTEREST
}

\author{
Jared C. Quinn
}

\section{$(\mathrm{cc})$ EY-NG-ND}

This work is licensed under a Creative Commons Attribution-Noncommercial-No Derivative Works 3.0 United States License.

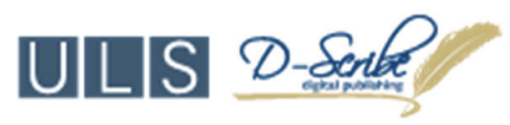

This journal is published by the University Library System of the University of Pittsburgh as part of its D-Scribe Digital Publishing Program, and is cosponsored by the University of Pittsburgh Press. 


\title{
CONGRESS SHOULD HAVE AN INTEREST IN THIS INTEREST
}

\author{
Jared C. Quinn*
}

Growing up in Western Pennsylvania, I learned about the history of Pittsburgh's steel industry, and its effect on Pittsburgh's residents today. After all, Western Pennsylvania was a steel manufacturing giant. ${ }^{1}$ During the latter half of the twentieth century, the steel mill exodus began in Western Pennsylvania. ${ }^{2}$ After most of the mills departed the area, thousands of people struggled to make ends meet. ${ }^{3}$ The devastating effect of all the lost blue-collar jobs can still be seen today. ${ }^{4}$ Most of the steel mills and associated factories disappeared from Western Pennsylvania, but the thousands of unskilled workers who lost their jobs at these steel mills and associated factories remained. ${ }^{5}$

Faced with the harsh realities of lacking a meaningful education, skills, or family to support them financially, many of these financially distressed debtors mortgaged their homes, took out car loans, and owed significant amounts of taxes. ${ }^{6}$ We can imagine that these people would look for other options to resolve their financial issues, as their debts would increase

${ }^{*}$ Candidate for JD, 2019, University of Pittsburgh School of Law.

${ }^{1}$ Len Boselovic, Steel Standing, PitT. Post-GazetTe, Feb. 25, 2001, at C-1.

2 Pittsburgh, EnCYClopedia BritanNica (15th ed. 2010). The steel industry left Western Pennsylvania and Eastern Ohio between 1970 and 1990. Id. During this time, the Western District of Pennsylvania Bankruptcy Court was the venue of many of the steel manufacturers' bankruptcy cases. Id.

${ }^{3}$ David Streitfeld, Survival Lesson in Pittsburgh: Shedding an Industrial Past, N.Y. TIMES, Jan. 8, 2009 , at A1.

${ }^{4}$ Bill Toland, In Desperate 1983, There Was Nowhere for Economy to Go but Up, PITT. PosTGAZETTE, Dec. 23, 2012, at D-2.

${ }^{5}$ Introduction to Pittsburgh, VISITPITTSBURGH, https://www.visitpittsburgh.com/aboutpittsburgh/history/ (last visited Mar. 3, 2019).

${ }^{6}$ See Toland, supra note 4.

Pitt Tax Review | ISSN 1932-1821 (print) 1932-1996 (online) DOI 10.5195/taxreview.2019.100 | http://taxreview.law.pitt.edu 


\section{6 | Pittsburgh Tax Review | Vol. 162019}

tremendously over time due to interest. ${ }^{7}$ The effects on these people are still present. ${ }^{8}$ This lingering effect caused me to wonder: How does the interest on a debtor's taxes affect debtors postbankruptcy? Is this debt discharged? If not, why not, and is this fair?

To answer these questions, there is a lot we need to understand about debt, interest, and bankruptcy. This will be discussed below. As precursor to that information, please keep in mind that, as of 2018, the average mortgage debt in the United States is well over $\$ 100,000$, and in some states, it can be two or three times that amount. ${ }^{9}$ This is clearly a lot of money, and maybe even more to someone in bankruptcy. While some people may think they can afford their mortgage payments, many debtors prior to bankruptcy overlook interest payments. ${ }^{10}$ Interest can transform an apparently affordable mortgage, car loan, or even unpaid taxes into an unaffordable debt. ${ }^{11}$ Interest can be the catalyst that accelerates a debtor's slide into bankruptcy. ${ }^{12}$ Once in bankruptcy, the debtor will seek a discharge of his or her debts for financial relief. $^{13}$

A discharge in bankruptcy releases a debtor from personal liability for many debts in order to grant the debtor a fresh start after bankruptcy. ${ }^{14} \mathrm{~A}$ debtor may expect certain debts — such as interest - to be discharged after

\footnotetext{
${ }^{7}$ See id. See also Chris Seabury, How Interest Rates Affect the U.S. Markets, INVESTOPEDIA, https:// www.investopedia.com/articles/stocks/09/how-interest-rates-affect-markets.asp (last updated Oct. 15, 2018).

${ }^{8}$ See Toland, supra note 4.

${ }^{9}$ Susan Henson, How Much Americans Owe on Their Mortgages in Every State, EXPERIAN, https://www.experian.com/blogs/ask-experian/how-much-americans-owe-on-their-mortgages-in-everystate/ (last updated Jan. 23, 2018). The average mortgage debt in Pennsylvania is about $\$ 161,000.00$. Id.

${ }^{10}$ Steve Fiorillo, What Is Bankruptcy? Different Types and Why People File, THEStREeT (Sept. 11, 2018, 2:32 PM), https://www.thestreet.com/markets/bankruptcy/what-is-bankruptcy-14708068.

${ }^{11}$ See id.

${ }^{12}$ See Peter Dunn, Don't Be Debt Delusional: Quit Buying Stuff You Can't Afford!, USA TODAY (Aug. 27, 2016, 7:30 AM), https://www.usatoday.com/story/money/personalfinance/2016/08/27/debtafford-affordable-credit-cards/88757792/.

${ }^{13}$ Discharge in Bankruptcy - Bankruptcy Basics, U.S. COURTS, http://www.uscourts.gov/servicesforms/bankruptcy/bankruptcy-basics/discharge-bankruptcy-bankruptcy-basics (last visited Mar. 6, 2019).

${ }^{14} I d$.
}

Pitt Tax Review | ISSN 1932-1821 (print) 1932-1996 (online) DOI 10.5195/taxreview.2019.100 | http://taxreview.law.pitt.edu 
bankruptcy. ${ }^{15}$ This may be especially true for interest that accumulates while the debtor is in bankruptcy. ${ }^{16}$ For debtors, interest is just more money that needs to be paid to the debtors' creditors. ${ }^{17}$ However, debtors need to keep in mind that interest payments, especially interest on nondischargeable taxes, can still come back to haunt them postbankruptcy, ${ }^{18}$ because it currently may not be discharged. ${ }^{19}$ This is not fair.

In this Note, I argue that to avoid unnecessary harm to debtors in bankruptcy, postpetition interest on tax claims should be discharged in bankruptcy to help ensure that debtors receive a fresh start. I question the current applicability of a Supreme Court decision, Bruning v. United States, which states that postpetition interest on certain taxes are not discharged postbankruptcy. ${ }^{20}$ In Part I, I begin by explaining some of the basics of bankruptcy such as why debtors file for bankruptcy, what debts are and are not dischargeable, and the issue posed in Bruning. In Part II, I explain how case law has developed since Bruning was decided in 1964, over fifty years ago. Then, in Part III, I discuss how the Bankruptcy Code ${ }^{21}$ and Internal Revenue Code $^{22}$ support the proposition that postpetition interest should be discharged. Finally, in Part IV, I explain the public policy reasons why Congress should revisit, clarify, and change the current position on

${ }^{15}$ E.g., The Top Ten Bankruptcy Myths, WeSTBROOK LAw FIRM, http://www.westbrooklawtexas .com/bankruptcy-lawyer/bankruptcy-myths/ (last visited Mar. 6, 2019) ("Bankruptcy helps eliminate the negative consequences of your unpaid debts, whether you file under Chapter 7 or Chapter 13. All negative activity will terminate, including interest, late fees, collection fees, and attorney fees.").

${ }^{16}$ See id.

${ }^{17}$ Post Judgment Interest Calculator, U.S. BANKR. CourT: DisT. OF MASS., http://www.mab .uscourts.gov/mab/post-judgment-interest-calculator (last visited Mar. 6, 2019).

${ }^{18}$ In this Note, I will refer to time periods such as "postpetition," "postbankruptcy," and "postbankruptcy." In a typical bankruptcy case, a petition is filed with the clerk of the bankruptcy court, thereby beginning the debtor's bankruptcy case. See Discharge in Bankruptcy-Bankruptcy Basics, supra note 13. The time before filing the petition will be referred to as "pre-petition." "Post-petition" will be used to refer to the time period after the filing of the petition, but before discharge. Finally, "postbankruptcy" refers to the time after the debtor receives his or her discharge.

${ }^{19}$ See infra Part I.A.

${ }^{20}$ Bruning v. United States, 376 U.S. 358, 363 (1964); Discharge in Bankruptcy-Bankruptcy Basics, supra note 13.

${ }^{21}$ The Bankruptcy Code can be found in title eleven on the United States Code.

${ }^{22}$ The Internal Revenue Code can be found in title twenty-six on the United States Code.

Pitt Tax Review | ISSN 1932-1821 (print) 1932-1996 (online) DOI 10.5195/taxreview.2019.100 | http://taxreview.law.pitt.edu 


\section{8 |Pittsburgh Tax Review | Vol. 162019}

dischargeability of taxes to benefit a debtor's fresh start following bankruptcy.

\section{BANKRUPTCY AND THE BRUNING DECISION}

Bankruptcy is a useful solution for many "honest but unfortunate debtor[s]." ${ }^{23}$ For most debtors, it is a means to achieve a "stay" ${ }^{24}$ on debt collection by creditors. ${ }^{25}$ The stay gives the debtor a "breathing spell" against his or her creditors, because the creditors cannot seek payment of the debt during the stay. ${ }^{26}$

Filing for bankruptcy should not be the first option for debtors, but for some it is a first stop. ${ }^{27}$ This may be because the Bankruptcy Code's purpose "is to provide a procedure by which [many] insolvent debtors can reorder their affairs, make peace with their creditors, and enjoy 'a new opportunity in life and a clear field for future effort, unhampered by the pressure and discouragement of preexisting debt." ${ }^{28}$ This is clearly an important public policy consideration. ${ }^{29}$ Therefore, Congress should continue to pass legislation that promotes this purpose, to help debtors so they are not hampered by the pressure and discouragement of preexisting debt.

\footnotetext{
${ }^{23}$ Grogan v. Garner, 498 U.S. 279, 287 (1991).

${ }^{24}$ See generally Carron Armstrong, Removing Bankruptcy's Automatic Stay, THE BALANCE, https://www.thebalance.com/removing-bankruptcy-s-automatic-stay-introduction-316179 (last updated May 31,2018$)$. In bankruptcy, the stay prevents creditors and debt collectors from contacting a debtor in an attempt to collect money owed. Id.

${ }^{25}$ See 11 U.S.C. $\$ 362$ (a) (2012).

${ }^{26}$ H.R. REP. NO. 95-595, at 121 (1977), as reprinted in 1978 U.S.C.C.A.N. 5963, 6082.

27 Jeff Rose, Why Avoid Bankruptcy?, Good Fin. Cents (Feb. 25, 2019), https://www.goodfinancialcents.com/avoid-bankruptcy-rules/.

${ }^{28}$ Grogan, 498 U.S. at 286 (citing Local Loan Co. v. Hunt, 292 U.S. 234, 244 (1934)).

${ }^{29} I d$.
}

Pitt Tax Review | ISSN 1932-1821 (print) 1932-1996 (online) DOI 10.5195/taxreview.2019.100 | http://taxreview.law.pitt.edu 


\section{A. The Basics}

There are six types of bankruptcy ${ }^{30}$ but only three are widely utilized. ${ }^{31}$ The most relevant chapters of bankruptcy are Chapters 7,11 , and $13 .{ }^{32}$ For a price, many debtors seek relief through bankruptcy. All debtors who file for any type of bankruptcy have one goal in mind, to obtain a discharge of debts. ${ }^{33}$ But what is a discharge?

A "discharge releases the debtor from personal liability for certain specified types of debts." ${ }^{34}$ But again, there is a price to be paid. In many cases, in return for a discharge of debt, debtors must liquidate their assets, and can only keep their claimed exemptions. "Exemption statutes create 'safe harbors' withdrawing specific assets from [a debtor's] bankruptcy estate, allowing the debtor to maintain the property throughout the bankruptcy process." ${ }^{36}$ It is through this process that most debtors gain a fresh start, free of most debt. ${ }^{37}$

Debtors face the possibility of losing some of their possessions, losing lines of credit, paying higher interest rates postbankruptcy, and other consequences. ${ }^{38}$ Needless to say, some debtors in bankruptcy have already

30 Steve Nitz, The Different Chapters of Bankruptcy Explained, NAT'L FOUND. CREDIT COUNSELING (Sept. 22, 2017), https://www.nfcc.org/blog/different-chapters-bankruptcy-explained/.

${ }^{31}$ Bankruptcy Law-Chapter 7, 11, 13, HG.ORG, https://www.hg.org/bankrpt.html (last visited Mar. 6, 2019).

${ }^{32} I d$.

${ }^{33}$ Discharge in Bankruptcy-Bankruptcy Basics, supra note 13.

${ }^{34} I d$.

3511 U.S.C. \$ 522(b) (2012); David Carnes, What Assets Are Liquidated in a Chapter 7?, LEGALZOOM, https://info.legalzoom.com/assets-liquidated-chapter-7-23601.html (last visited Mar. 6, 2019).

${ }^{36}$ In re Way, No. 12-60209, 2014 Bankr. LEXIS 3985, at *7 (Bankr. N.D. Ohio Sept. 17, 2014).

37 John O'Connor, Exemptions: What Can I Keep if I File Bankruptcy?, https://www .natlbankruptcy.com/exemptions-what-can-i-keep-if-i-file-bankruptcy/ (last updated Dec. 26, 2017).

${ }^{38}$ Bankruptcy Pros and Cons, AM. BAR Assoc. (Mar. 18, 2013), https://www.americanbar.org/ groups/public_education/resources/law_issues_for_consumers/bankruptcy_disadvantages.html.

Pitt Tax Review | ISSN 1932-1821 (print) 1932-1996 (online) DOI 10.5195/taxreview.2019.100 | http://taxreview.law.pitt.edu 
gone through significant hardship. ${ }^{39}$ After all, debtors file for bankruptcy because they are financially distressed and may be experiencing medical issues or unemployment. ${ }^{40}$ Depending on the circumstances of each individual debtor, a different chapter of bankruptcy may be used to achieve that debtor's financial goals. ${ }^{41}$ But what are the basics to receiving a discharge in each chapter of bankruptcy?

The process for a bankruptcy court to order a discharge in a Chapter 7 case is relatively quick and simple compared to the other chapters of bankruptcy. ${ }^{42}$ In return for a discharge of debt, debtors must liquidate their assets, and can only keep their claimed exemptions in a Chapter 7 bankruptcy. ${ }^{43}$ The Chapter 7 process usually takes the bankruptcy court sixty to ninety days after the meeting of the creditors is completed. ${ }^{44}$ However, there are other bankruptcy processes required by the Bankruptcy Code that do not result in as quick a discharge of debt. ${ }^{45}$

For debtors who do not wish to lose almost all of their nonexempt assets in a Chapter 7 bankruptcy, or for those who fail the means test, ${ }^{46}$ Chapter 13 bankruptcy may be necessary or required by law. ${ }^{47}$ The means test is an

${ }^{39}$ See, e.g., Top 10 Reasons People Go Bankrupt, HufFInGTON Post, https://www.huffingtonpost .com/simple-thrifty-living/top-10-reasons-people-go-_b_6887642.html (last updated May 24, 2015).

${ }^{40} \mathrm{Id}$.

${ }^{41}$ See Bankruptcy Law-Chapter 7, 11, 13, supra note 31.

${ }^{42}$ See id.

${ }^{43}$ See, e.g., Discharge in Bankruptcy—Bankruptcy Basics, supra note 13.

44 Chapter 7-Bankruptcy Basics, U.S. COURTS, http://www.uscourts.gov/services-forms/ bankruptcy/bankruptcy-basics/chapter-7-bankruptcy-basics (last visited Mar. 7, 2019). The meeting of creditors occurs soon after the debtor files for bankruptcy. Id.

${ }^{45}$ Russ B. Cope, What Is the Fastest Way to Get Out of Debt?, NAT'L BANKR. Forum, https://www .natlbankruptcy.com/what-fastest-way-get-out-debt/ (last updated Nov. 13, 2017).

${ }^{46}$ The means test is a relatively simply financial calculation that determines whether a debtor may file for Chapter 7 bankruptcy. Chapter 7-Bankruptcy Basics, supra note 44. Until the Bankruptcy Abuse Prevention and Consumer Protection Act (BAPCPA) was passed in 2005, there were significantly more Chapter 7 filings than Chapter 13 filings. Congress intended to require more debtors to file for Chapter 13 rather than Chapter 7. "Our legislation will direct more filers into Chapter 13 plans and make sure that those who can afford to repay a substantial part of their debt are required to do so." 145 CONG. REC. 8514 (1999). BAPCPA made the means test a requirement when filing for bankruptcy. Chapter 7-Bankruptcy Basics, supra note 44.

${ }^{47}$ See 11 U.S.C. $\S \S 109(e), 707(b)(1)(2012)$.

Pitt Tax Review | ISSN 1932-1821 (print) 1932-1996 (online)

DOI 10.5195/taxreview.2019.100 | http://taxreview.law.pitt.edu 
evaluation of each individual debtor to determine if the debtor's income is low enough to allow the debtor to file for a Chapter 7 bankruptcy. ${ }^{48}$ If the debtor's income is over a predetermined amount in the debtor's jurisdiction, then the debtor cannot file a Chapter 7 bankruptcy, but may need to file a Chapter 13 bankruptcy. ${ }^{49}$ For example, a single debtor in Pennsylvania could not file for Chapter 7 bankruptcy in 2018 if his or her income was over $\$ 53,067 .{ }^{50}$ A debtor with income over this amount would have to file for a Chapter 13 bankruptcy.

In its simplest form, a Chapter 13 bankruptcy is a three-to five-year repayment plan. ${ }^{51}$ A Chapter 13 bankruptcy allows debtors to catch up on their arrears and repay creditors over a period of time. ${ }^{52}$ Over the three to five years after the debtor files for bankruptcy, the debtor must dedicate all of his or her disposable income to the debtor's creditors and make regular payments to a Chapter 13 Trustee. ${ }^{53}$ The debtor's three- to five-year plan will determine what debts are paid and how much the creditors will receive throughout the plan. ${ }^{54}$ While a Chapter 13 bankruptcy is beneficial for a debtor who wants to keep his or her home, the debtor will not receive a discharge as quickly as the debtor would in a Chapter 7 proceeding. ${ }^{55}$ The discharge comes only once the debtor makes all the required payments over the three to five years. ${ }^{56}$ This long time period allows for a significant amount of interest to accrue.

\footnotetext{
${ }^{48}$ See Chapter 7-Bankruptcy Basics, supra note 44.

${ }^{49} \mathrm{Id}$.

${ }^{50}$ Census Bureau Median Family Income By Family Size, United States Dep’t of Just., https://www.justice.gov/ust/eo/bapcpa/20171101/bci_data/median_income_table.htm (last visited Mar. 29, 2019); Means Testing, UNITED STATES DEP'T OF Just. (last update Oct. 15, 2018), https://www .justice.gov/ust/means-testing/20180501.

${ }^{51}$ Latoya Irby, Chapter 13 Bankruptcy, THE BALANCE, https://www.thebalance.com/chapter-13bankruptcy-overview-960055 (last updated Jan. 16, 2019).

${ }^{52} I d$.

${ }^{53} I d$. The petition date is the date that the debtor files for bankruptcy. Id.

${ }^{54} \mathrm{Id}$.

${ }^{55}$ See Discharge in Bankruptcy —Bankruptcy Basics, supra note 13.

${ }^{56}$ See 11 U.S.C. § 1328(a) (2012).
}

Pitt Tax Review | ISSN 1932-1821 (print) 1932-1996 (online) DOI 10.5195/taxreview.2019.100 | http://taxreview.law.pitt.edu 


\section{2 | Pittsburgh Tax Review | Vol. 162019}

Finally, a Chapter 11 bankruptcy is similar to a Chapter 13 bankruptcy. ${ }^{57}$ The debtor in a Chapter 11 bankruptcy, called the "debtor in possession," files a plan which is voted upon by its creditors. ${ }^{58}$ "Chapter 11 is typically used to reorganize a business, [such as] a corporation, sole proprietorship, or partnership"; however, it may be used by individuals as well. ${ }^{59}$ The general rule to determine the debtor in possession's discharge is that a judicial order confirming the debtor's plan operates as a discharge. ${ }^{60}$ The timing will depend on the circumstances of the case. ${ }^{61}$

Now that the most commonly utilized chapters in the Bankruptcy Code have been explained, we should try to understand the basic problem that postpetition interest poses to debtors in bankruptcy. Interest is the cost to use money over time. ${ }^{62}$ Interest is also an incentive for a debtor to promptly repay his or her debts. ${ }^{63}$ Interest can interfere with the debtor's main goal in bankruptcy: to discharge debts as quickly as possible. ${ }^{64}$ Especially because a Chapter 13 bankruptcy significantly increases the amount of time that interest can accumulate on taxes and other debts postpetition, the amount of interest could be huge for a debtor. ${ }^{65}$ A debtor may hope for all of his or her debtincluding interest — to be discharged; ${ }^{66}$ however, this may be a false hope. ${ }^{67}$

It should come as no surprise that not all debts are discharged in bankruptcy. ${ }^{68}$ For example, domestic support obligations, like child support,

${ }^{57}$ See Bankruptcy Law-Chapter 7, 11, 13, supra note 31.

${ }^{58}$ See Chapter 11-Bankruptcy Basics, U.S. COURTS, http://www.uscourts.gov/services-forms/ bankruptcy/bankruptcy-basics/chapter-11-bankruptcy-basics (last visited Mar. 8, 2019).

${ }^{59} \mathrm{Id}$.

${ }^{60} I d$.

${ }^{61} \mathrm{Id}$.

${ }^{62}$ Bruning v. United States, 376 U.S. 358, 360 (1964).

${ }^{63} \mathrm{Id}$.

${ }^{64}$ Discharge in Bankruptcy-Bankruptcy Basics, supra note 13.

${ }^{65}$ Interest accumulates when all disposable income for a three- to five-year plan is used and no payments are directed to decrease the principal balance on which the interest is accruing.

${ }^{66}$ The Top Ten Bankruptcy Myths, supra note 15.

${ }^{67}$ See infra Part I.B.

${ }^{68} 11$ U.S.C. § 523(a) (2012).

Pitt Tax Review | ISSN 1932-1821 (print) 1932-1996 (online) DOI 10.5195/taxreview.2019.100 | http://taxreview.law.pitt.edu 
or money owed for a willful or malicious injury may not be discharged. ${ }^{69}$ Also, a common theme in bankruptcy is "that liens pass through bankruptcy unaffected. ${ }^{, 70}$ Thus, liens, ${ }^{71}$ such as home mortgages, are not discharged. ${ }^{72}$ These exceptions are usually limited to secured claims. ${ }^{73}$ In bankruptcy, secured claims are secured by some type of property. ${ }^{74}$ A secured claim "allows a secured creditor [even a taxing body, who obtained a lien, to not] participate in the bankruptcy case and instead to look to its pre-existing lien for the satisfaction of its debt after the debtor has emerged from bankruptcy." 75 While there are caveats and judicial exceptions to this general rule, ${ }^{76}$ most liens will not be discharged. ${ }^{77}$

Some claims never even come into bankruptcy. Claims for postpetition, unmatured $^{78}$ interest are not allowed in bankruptcy. " ${ }^{79}$ "A]s a general rule, creditors are not entitled to interest that has not accrued as of the petition

${ }^{69} I d . \S 523(\mathrm{a})(5)-(6)$.

${ }^{70}$ Hamlett v. Amsouth Bank (In re Hamlett), 322 F.3d 342, 348 (3d Cir. 2003) (citing Dewsnup v. Timm, 502 U.S. 410, 417 (1992)).

${ }^{71}$ Liens may be consensual such as a mortgage or nonconsensual such as a judicial lien. E.g., Grace Keh, What Are the Various Types of Liens?, POCKETSENSE, https://pocketsense.com/various-types-liens24286.html (last visited Mar. 9, 2019).

${ }^{72}$ Hamlett, 322 F.3d at 350; Jean Murray, What Is a Lien and How Does It Work?, THE BALANCE: SMALl Bus., https://www.thebalancesmb.com/what-is-a-lien-and-how-does-it-work-398313 (last updated July 15, 2018).

${ }^{73} 11$ U.S.C. $\S 101(5)$ (2012). As defined by the Bankruptcy Code, a claim is a right to payment of a creditor. Id. Secured claims are governed by each state's respective version of Article 9 of the Uniform Commercial Code. U.C.C. § 9-301(1) (AM. LAW INST. \& UNIF. LAW COMM’N 2010); id. § 9-307(b)-(c).

${ }^{74}$ See 11 U.S.C. § 101(37) (2012).

${ }^{75}$ Mark D. Collins, Do Pre-existing Liens Really Pass Through Bankruptcy Unaffected, AM. BANKR. INST. J., Nov. 1999, at 9.

${ }^{76} \mathrm{Id}$.

${ }^{77}$ Dewsnup v. Timm, 502 U.S. 410, 418 (1992). Examples of liens that would not pass through bankruptcy are unallowed secured claims and liens that impair the debtor's exemptions under $\S 522(\mathrm{~b})$ of the Bankruptcy Code. 11 U.S.C. $\S \S 506(d), 522(f)$ (2012).

${ }^{78}$ In re U.S. Lines Inc., 199 B.R. 476, 481 (Bankr. S.D.N.Y. 1996) Courts have explained that interest is unmatured when it has not been earned as of the petition date. Id.

${ }^{79} 11$ U.S.C. $\S 502(b)(2)$.

Pitt Tax Review | ISSN 1932-1821 (print) 1932-1996 (online) DOI 10.5195/taxreview.2019.100 | http://taxreview.law.pitt.edu 


\section{4 | Pittsburgh Tax Review | Vol. 162019}

date. ${ }^{80}$ In other words, interest stops accumulating on an unsecured ${ }^{81}$ tax claim when the debtor files his or her bankruptcy petition. ${ }^{82}$

In addition, there are other instances where holders of tax claims are entitled to interest throughout the life of a bankruptcy case. Interest accumulates on secured tax claims when the taxing body holds a lien on property. ${ }^{83}$ The amount of interest will continue to accrue through the life of the debtor's plan. However, this is a specific instance where the tax creditor is a secured creditor in the debtor's property. Most of the exceptions to debt discharge are expressly enumerated in the Bankruptcy Code. ${ }^{84}$ Yet, we must keep in mind that some statutes outside of the Bankruptcy Code, like the Internal Revenue Code, may also be interpreted to contain exceptions to discharge.

\section{B. The Bruning Decision}

In 1964, the Supreme Court heard a case regarding whether the type of interest rooted in $\S 6873$ of the Internal Revenue Code should be discharged in bankruptcy. This case was Bruning v. United States. The text of $\S 6873$ of the Internal Revenue Code states, "Any portion of a claim for taxes allowed in a receivership proceeding which is unpaid shall be paid by the taxpayer upon notice and demand from the Secretary after the termination of such proceeding. $" 85$ In order to understand this law today, we need to look at historical cases concerning $\S 6873$.

The specific issue the Supreme Court heard in Bruning v. United States was whether the Internal Revenue Service (IRS) was entitled to recover postpetition interest on a tax assessment of assets acquired by a debtor after his adjudication of bankruptcy, which was not discharged in the bankruptcy

${ }^{80}$ Jonathan S. Henes, Buyers of Secured Debt, Beware: Solutia Ruling Shows OID Risks, Dow JONES DAILY BANKR. REV. (Mar. 26, 2008), https://www.kirkland.com/publications/article/2008/03/ buyers-of-secured-debt-beware-solutia-ruling-shows.

${ }^{81}$ A claim that has no security in property.

${ }^{82}$ A significant number of tax claims are unsecured tax claims.

${ }^{83}$ See generally United States v. Ron Pair Enters., 489 U.S. 235, 238-39 (1989).

${ }^{84}$ See 11 U.S.C. $\$ 523$.

${ }^{85}$ I.R.C. § 6873(a).

Pitt Tax Review | ISSN 1932-1821 (print) 1932-1996 (online) DOI 10.5195/taxreview.2019.100 | http://taxreview.law.pitt.edu 
proceedings. ${ }^{86}$ It was undisputed that the debtor remained liable for the principal amount and the prepetition interest on the tax debt after discharge. ${ }^{87}$ However, the taxpayer brought action against the United States for a refund of postpetition interest on the debtor's income taxes. ${ }^{88}$

Before the Supreme Court heard the case, the district court held that the taxpayer/bankrupt's personal liability for postpetition interest on the unpaid taxes was not discharged by the bankruptcy proceedings, and the U.S. Court of Appeals for the Ninth Circuit affirmed the district court's decision. ${ }^{89}$ Then, the Supreme Court reviewed the case to resolve this issue. ${ }^{90}$

Chief Justice Warren delivered a relatively short opinion. He stated that under $\S 6873$, postpetition interest on an unpaid tax debt was not discharged as a personal liability of the debtor. ${ }^{91}$ The Court held that $\S 6873$ means that the debtor "remains personally responsible for post-petition accrued interest." "92 Furthermore, the Court determined that Congress "intended personal liability to continue as to the interest on that debt as well as to its principal amount." ${ }^{93}$ It was never "seriously suggested that a creditor... loses his right to interest in a postbankruptcy action brought against the debtor personally." 94 Additionally, the Court stated that interest is "an integral part of a [nondischargeable] debt," like taxes. ${ }^{95}$ The Supreme Court found no reason to reverse the district and circuit courts' holdings. "The Bruning decision therefore stands for the ... proposition that ... the debtor [will owe and accrue] post-petition interest on nondischargeable debts while

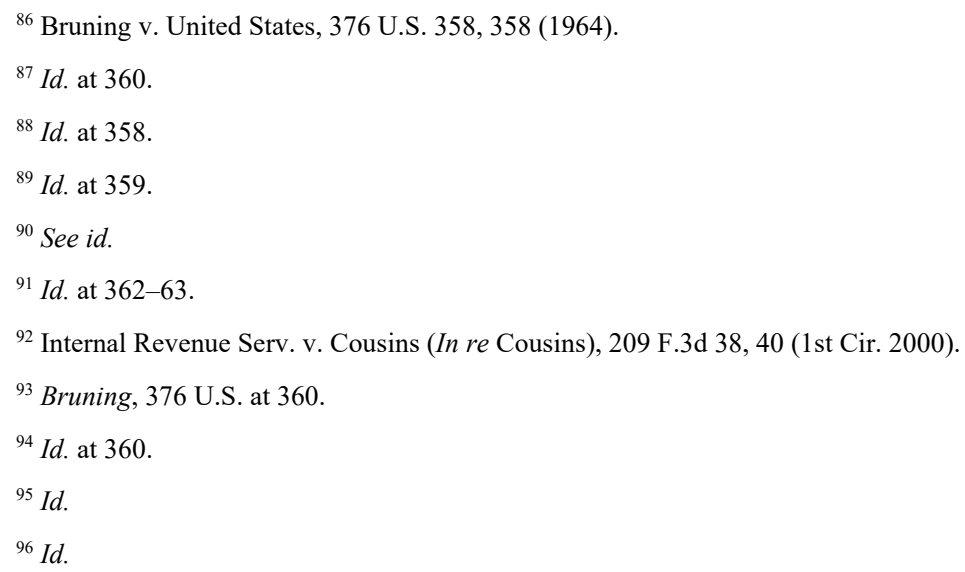




\section{6 | Pittsburgh Tax Review | Vol. 162019}

a bankruptcy is pending. ${ }^{, 97}$ Let us look at how case law has developed since Bruning.

\section{HOW THE LAW HAS DEVELOPED POST-BRUNING}

In the many years after Bruning, the decision has not been overturned. Courts have expanded upon Bruning using the Supreme Court's reasoning for not discharging postpetition interest. ${ }^{98}$ There are numerous reasons, discussed below, ${ }^{99}$ why courts have stuck by this holding, but one of the most important reasons seems to be that taxes and the interest on such taxes are vital funding sources for the nation. ${ }^{100}$

Notwithstanding the Bruning decision and other cases applying its reasoning, the Supreme Court has decided at least one case that seems to contradict Bruning. This case is Kawaauhau v. Geiger; and in this case the Court held that only those expressly indicated exceptions to discharge should apply. ${ }^{101}$ There is no express exception in the Bankruptcy Code for postpetition interest. For the result in the Bruning decision to still apply now, there would need to be an express exception. Therefore, under Kawaauhau v. Geiger, postpetition interest should be discharged because there is no express exception. But let's first examine the reasoning for still applying the Bruning decision.

\section{A. Reasoning for Upholding Bruning}

To determine whether the Bruning decision should still be applied, the questions we need to understand are: Why does the government wish to receive interest even though it affects a debtor's fresh start? Why isn't interest discharged? What proof do courts use to validate any congressional intent? And how does this compare to other cases, such as Kawaauhau v. Geiger, that the Supreme Court has decided?

\footnotetext{
${ }^{97}$ Leeper v. Pa. Higher Educ. Assistance Agency, 49 F.3d 98, 102 (3d Cir. 1995).

${ }^{98} I d$. at 101.

${ }^{99}$ See infra Part II.A.

${ }^{100}$ See Kawaauhau v. Geiger, 523 U.S. 57, 62 (1998).

${ }^{101} I d$. at 62 .
}

Pitt Tax Review | ISSN 1932-1821 (print) 1932-1996 (online) DOI 10.5195/taxreview.2019.100 | http://taxreview.law.pitt.edu 
Looking at case law, we can see why the government wants to receive postpetition interest postbankruptcy, and why interest is not discharged. In In re Hamilton, the Ninth Circuit applied the Bruning court's holding. ${ }^{102}$ As in Bruning, the court reasoned that interest was "an integral part of a continuing debt." 103 The Ninth Circuit also stated that the purpose of interest "is to compensate the successful plaintiff for being deprived of compensation for the loss of time between the ascertainment of the damage and the payment by the defendant." 104 Therefore, interest was not discharged postbankruptcy. ${ }^{105}$

Additionally, in United States v. Friendship College, the Fourth Circuit made evident that interest is an integral part of tax debt. ${ }^{106}$ The court determined that interest on taxes should not be treated differently than the taxes themselves. ${ }^{107}$ In the end, the court held that interest accrued should not be discharged, but rather paid by the debtor as in Bruning. ${ }^{108}$

It should come as no surprise that the U.S. government uses taxes to fund public projects. ${ }^{109}$ With this common knowledge, and using the previously discussed cases, we can reason that the government views receiving interest as a critical part of taxing its citizens, and that the United States does not want to be deprived of any money that could be used to fund the nation. To say the least, this is an important public policy interest.

Next, there is additional reasoning courts have used to continuously apply the Bruning holding. Again, we can look to Friendship College and

${ }^{102}$ Hamilton v. Elite of L.A., Inc. (In re Hamilton), 584 B.R. 310, 322 (9th Cir. 2018).

${ }^{103}$ Id. at 322 (citing Bruning v. United States, 376 U.S. 358, 360 (1964)).

${ }^{104}$ Id. at 323 (citing United States v. Bell, 602 F.3d 1074, 1083 (9th Cir. 2010)).

${ }^{105}$ Id.

${ }^{106}$ See generally United States v. Friendship College, Inc., 737 F.2d 430, 433 (4th Cir. 1984).

${ }^{107}$ See id. at 431; see also United States v. Ringley, 985 F.2d 185, 188 (4th Cir. 1993) (citing Ann Catino, Comment, Is the Abandoned Mine Reclamation Fee Discharged in Bankruptcy?, 2 J. MiN. L. \& POL'Y 243, 257 (1986)). The court in Ringley notes that at least one circuit, and a number of Bankruptcy Courts, concluded that some taxes that are not dischargeable under the Bankruptcy Code. Ringley, 985 F.2d at 187-88.

\footnotetext{
${ }^{108}$ Friendship College, 737 F.2d at 433.

${ }^{109}$ See I.R.S. Pub. No. 2105, Why Do I Have to Pay Taxes? 1 (2011).
}

Pitt Tax Review | ISSN 1932-1821 (print) 1932-1996 (online) DOI 10.5195/taxreview.2019.100 | http://taxreview.law.pitt.edu 
that Court's reasoning to require postpetition interest to be paid by the debtor postbankruptcy. ${ }^{110}$ Courts have indicated that for this interest to be treated differently, they require proof in one form or another. ${ }^{111}$ However, we should be skeptical of this, because courts have not found any express congressional proof. ${ }^{112}$ This lack of express congressional proof even divided courts as to whether interest on taxes is allowed during bankruptcy at all. ${ }^{113}$

To resolve this issue, some courts looked to treat interest as an administrative expense. ${ }^{114}$ Administrative expenses are expenses that "arise[] after the official date of the bankruptcy filing, and [are] related to costs that are necessary to preserve the estate." 115 Courts have held that interest on a tax incurred by the bankruptcy estate is payable as an administrative claim, because the failure to expressly list interest in the Bankruptcy Code does not necessarily exclude it. ${ }^{116}$ Courts seem to have manufactured congressional intent to prevent the discharge of postpetition interest, but these courts still have not discovered conclusive proof of Congress's intent. The Friendship College Court found its only proof in a 1978 report of the Senate Judiciary Committee:

[T]he only indication we have one way or the other suggests that interest should be first priority, see, Report of the Senate Judiciary Committee, S. Rep. No. 95989, 95th Cong., 2d. Sess. (1978), at 66, reprinted in, 1978 U.S. Code Cong. \& Admin. News, 5787, where it was stated that interest on first priority taxes should also receive first priority treatment. We therefore opt for consistency. ${ }^{117}$

\footnotetext{
${ }^{110}$ See, e.g., Friendship College, 737 F.2d at 433.

${ }^{111} I d$.

${ }^{112}$ See id.

${ }^{113}$ Elizabeth Lea Black, Annotation, What Are "Administrative Expenses" Under $\$ 503$ (b) of Bankruptcy Code (11 U.S.C.A. § 503(b)) Granted First Priority for Payment Pursuant to $\$$ 507(a)(1) of Code (11 U.S.C.A. $\$ 507(a)(1)), 140$ A.L.R. Fed. 1 \$ 42[a] (1997).

${ }^{114} \mathrm{Id}$.

115 Administrative Expense Claim, USLEGAL, https://definitions.uslegal.com/a/administrativeexpense-claim/ (last visited Mar. 9, 2019).

${ }^{116}$ See, e.g., Nicholas v. United States, 384 U.S. 678, 689 (1966).

${ }^{117}$ Friendship College, 737 F.2d at 433.
}

Pitt Tax Review | ISSN 1932-1821 (print) 1932-1996 (online) DOI 10.5195/taxreview.2019.100 | http://taxreview.law.pitt.edu 
In addition, the Fourth Circuit in Friendship College noted that interest was not mentioned in $\S 503$ of the Bankruptcy Code. ${ }^{118}$ Section 503 addresses administrative expenses that are given priority in the Bankruptcy Code. ${ }^{119}$ Even though the court found little justification for its decision, it still held that there should not be differing treatment between a priority tax claim or the interest accumulating on the tax. ${ }^{120}$

Deciding to opt for consistency in past cases regarding the ability to discharge interest, the court held that the Bankruptcy Code allowed for treating interest as an administrative expense under $\S 503 .{ }^{121}$ Therefore, cases since Bruning have held that interest accrued on claims postpetition cannot be discharged, and the courts have found no clear proof to treat this type of interest otherwise. ${ }^{122}$ Therefore, courts have determined that postpetition interest is still not dischargeable, but payable by the debtor postbankruptcy. This is an example of the reasoning courts have used to continuously apply the Bruning holding.

But are there reasons to question this determination? We saw that courts will "opt for consistency" when determining if interest should be discharged. ${ }^{123}$ Looking back at Bruning, the Court stated that "logic and reason indicate that post-petition interest on a tax claim excepted from discharge by $\S 17$ of the Act should be recoverable in a later action against the debtor personally, and there is no evidence of any congressional intent to the contrary." 124 Interestingly, the Court went on to say that the "general humanitarian purpose of the Bankruptcy Act provides no reason to believe that Congress had a different intention regarding personal liability for the interest on such debts." ${ }^{25}$ However, other cases and recent amendments to

\footnotetext{
${ }^{118}$ While this section does give taxes incurred by the estate priority, the section does not expressly include interest. $I d$.

11911 U.S.C. $\S 503$ (2012).

${ }^{120}$ Friendship College, 737 F.2d at 432-33.

${ }^{121} I d$. at 433.

${ }^{122} \mathrm{Id}$.

${ }^{123} \mathrm{Id}$.

${ }^{124}$ Bruning v. United States, 376 U.S. 358, 360 (1964) (emphasis added).

${ }^{125} \mathrm{Id}$. at 361 (emphasis added).
}

Pitt Tax Review | ISSN 1932-1821 (print) 1932-1996 (online) DOI 10.5195/taxreview.2019.100 | http://taxreview.law.pitt.edu 
the Bankruptcy Code signal the opposite intent. ${ }^{126}$ In other words, there is proof that could allow courts to conclude that Congress had a different intent and wanted to permit postpetition interest to be discharged. This would undermine the reasoning to continue to apply Bruning.

\section{B. Why There Is a Different Congressional Intent}

Thirty years after the Supreme Court's decision in Bruning, the Court decided a case that should help debtors discharge debts such as postpetition interest. In Kawaauhau v. Geiger, the Supreme Court stated that it is a "wellknown' guide that exceptions to discharge "should be confined to those plainly expressed." 127 According to this case, only those clearly expressed exceptions to discharge in the Bankruptcy Code should apply. ${ }^{28}$ Currently, postpetition interest is not the subject of any express exception from discharge.

Congress decides what discharge exceptions are enumerated in the Bankruptcy Code. 129 "But unless and until Congress makes such a decision, we must follow the current direction" that the bankruptcy statutes provide for exceptions to discharge. ${ }^{130}$ For example, Bankruptcy Code $\S 523(\mathrm{a})(6)$ expressly indicates that a debt "for willful and malicious injury by the debtor to another" is not dischargeable. The Supreme Court thus advocates that the exceptions to discharge should be clearly enumerated in the Bankruptcy Code, and courts should only allow those clearly expressed exceptions. ${ }^{131}$ Postpetition interest is not plainly included in an express exception to discharge, so, according to the Court's rationale, it should not be discharged.

${ }^{126}$ See Bankruptcy Abuse Prevention and Consumer Protection Act of 2005, Pub. L. No. 109-8, $\S$ 704(a), 119 Stat. 23, 125; see also Kawaauhau v. Geiger, 523 U.S. 57, 62 (1998). (1915))

${ }^{127}$ Kawaauhau, 523 U.S. at 62 (emphasis added) (quoting Gleason v. Thaw, 236 U.S. 558, 562

${ }^{128} \mathrm{Id}$.

${ }^{129} I d$. at 64 .

${ }^{130} I d$.

${ }^{131}$ Id.

Pitt Tax Review | ISSN 1932-1821 (print) 1932-1996 (online) DOI 10.5195/taxreview.2019.100 | http://taxreview.law.pitt.edu 
Kawaauhau was decided in 1998, and the Bankruptcy Code underwent a major change in $2005 .{ }^{132}$ In the most recent amendments to the Bankruptcy Code, postpetition interest on unsecured tax claims is neither expressly noted in $\S \S 523,727$, or 1328 , where the exceptions to discharge are located. ${ }^{133}$ For example, $\S 523(\mathrm{a})(6)$ of the Bankruptcy Code "permits the court to determine whether a debt is dischargeable." ${ }^{134}$ Nor is there any language in $\S \S 503$ or 507, where administrative and other priority taxes are discussed. ${ }^{135}$ Congress must have also been aware of the Kawaauhau decision when amending the Bankruptcy Code. Congress, as the writers of the Bankruptcy Code, must have been aware of this lack of expression before and after making any amendments to the Bankruptcy Code as well. Taken together, this indicates Congress's intent to except postpetition interest because no express language was added.

One case has specifically indicated that postpetition interest can be discharged. The court in In re Di Vincenzo stated that Congress intended to relieve the debtor from his or her financial hardships that result from having debts survive bankruptcy and to give the bankrupt a fresh start. ${ }^{136}$ "To continue the interest obligation as a liability against the bankrupt when the tax debt itself is discharged, would obviously defeat the policy of . . . aid[ing] in the financial rehabilitation of the bankrupt." 137 However, the relevant distinction in this case, compared to others, was that the prepetition interest and the tax obligation itself was due over three years prior to the bankruptcy. ${ }^{138}$ Thus, the court in this case held that interest was discharged, but it was only under these specific circumstances of the case. ${ }^{139}$ Regardless, the takeaway from this case is that the public policy of rehabilitating the

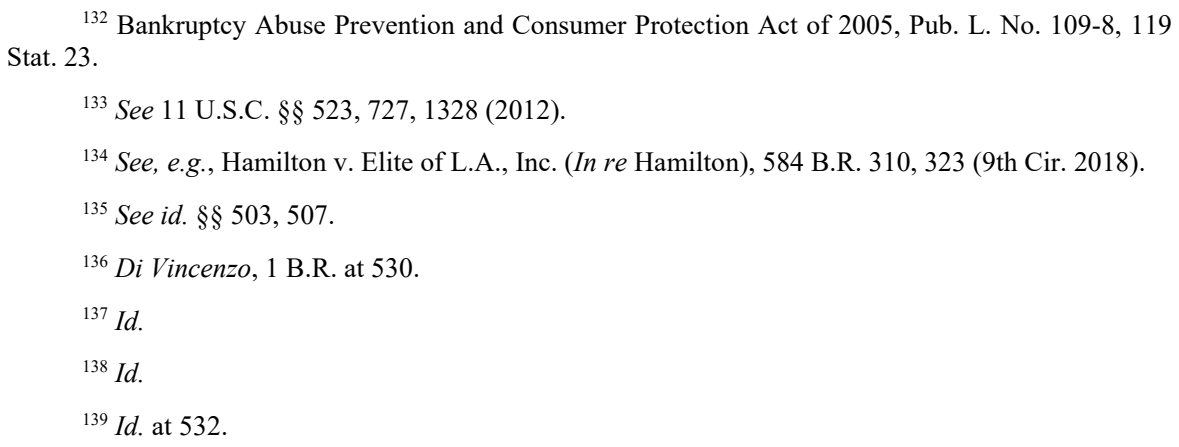

Pitt Tax Review | ISSN 1932-1821 (print) 1932-1996 (online) DOI 10.5195/taxreview.2019.100 | http://taxreview.law.pitt.edu 
bankrupt is a strong reason why postpetition interest should be discharged. This is especially relevant because no express statute exists that indicates whether interest can be discharged or not. ${ }^{140}$

After many years and multiple revisions of the Bankruptcy Code, ${ }^{141}$ Congress still has not expressly indicated whether interest should or should not be discharged, even though the Supreme Court has stated both that only express exceptions to discharge should apply and that public policy interests support giving debtors a fresh start. ${ }^{142}$ There seems to be conflicting guidance.

On the one hand, it is important for the government to receive the funds it needs to finance its activities, and courts have consistently upheld the Bruning decision. On the other hand, debtors deserve a fresh start. Also, it seems that the Supreme Court has indicated that Congress should clearly state that postpetition interest is nondischargeable if this is the result that Congress intended. ${ }^{143}$ Until Congress steps in to specifically provide otherwise, postpetition interest should be discharged. Courts should not be allowed to manufacture congressional intent to prevent the discharge of postpetition interest. In addition, Congress should be influenced by the current versions of the Bankruptcy and Internal Revenue Codes when determining whether postpetition interest should be discharged.

\section{A ClOSER LOOK AT THE BANKRUPTCY CODE AND INTERNAL REVENUE CODE}

To help understand whether postpetition tax interest should be discharged, hints are scattered throughout the Bankruptcy Code and the Internal Revenue Code. We can analyze specific statutes such as $\S \S 511$ and 1322 of the Bankruptcy Code, which expressly state at what rate and when interest is to be paid. ${ }^{144}$ Furthermore, we can look to $\S \S 503$ and 507 in the

${ }^{140}$ See 11 U.S.C. $\S \S 523,727,1328$ (2012).

${ }^{141}$ See, e.g., Bankruptcy Abuse Prevention and Consumer Protection Act of 2005, Pub. L. No. 1098,119 Stat. 23 .

\footnotetext{
${ }^{142}$ Kawaauhau v. Geiger, 523 U.S. 57, 62 (1998).

${ }^{143} I d$.

${ }^{144}$ See 11 U.S.C. $\S 511,1322$ (2012).
}

Pitt Tax Review | ISSN 1932-1821 (print) 1932-1996 (online) DOI 10.5195/taxreview.2019.100 | http://taxreview.law.pitt.edu 
Bankruptcy Code, which indicate how priority taxes are paid in bankruptcy. ${ }^{145}$ Next, we can examine the Bankruptcy Code's legislative history for congressional intent. Finally, we may compare $\S \S 6871$ and 6873 of the Internal Revenue Code to find specific drafting differences. Together, these statutes and their legislative histories indicate that postpetition interest should be discharged.

\section{A. Looking at the Bankruptcy Code}

To begin, we should consider whether Congress was aware of the postpetition interest issue when it drafted the most recent Bankruptcy Code. To determine this, we can look at $\S 511,{ }^{146}$ which determines the rate of interest on tax claims if the provision requires the payment of interest. The legislative history of $\S 511$ indicates that Congress, when drafting the Bankruptcy Code, expressly contemplated and included a provision relating to interest on taxes. ${ }^{147}$ With this in mind, we can deduce that Congress, due to Kawaauhau, was aware of a need for specific statutes relating to interest on taxes in bankruptcy. Since Congress had the requisite awareness of this issue, and no section of the Bankruptcy Code states that interest is an administrative or priority expense and no express exception to the discharge of postpetition interest can be found, postpetition interest should be discharged.

For over fifty years, Congress has had the opportunity to codify the Bruning decision. In addition, the Bankruptcy Code has undergone three major changes since Bruning. ${ }^{148}$ The most recent major change was the Bankruptcy Abuse Prevention and Consumer Protection Act of 2005 (BAPCPA). ${ }^{149}$ In the current Bankruptcy Code, there is a specific section that

\footnotetext{
${ }^{145}$ See id. $\S \S 503,507$.

${ }^{146}$ Congress added $\S 511$ of the Bankruptcy Code in 2005. Bankruptcy Abuse Prevention and Consumer Protection Act of $2005 \S 704(a), 119$ Stat. at 125.

${ }^{147} \mathrm{Id}$.

${ }^{148}$ Bankruptcy Abuse Prevention and Consumer Protection Act of 2005, 119 Stat. 23; Bankruptcy Amendments and Federal Judgeship Act of 1984, Pub. L. No. 98-353, 98 Stat. 333; Bankruptcy Reform Act of 1978, Pub. L. No. 95-598, 92 Stat. 2549.

${ }^{149}$ Bankruptcy Abuse Prevention and Consumer Protection Act of 2005, 119 Stat. 23.
}

Pitt Tax Review | ISSN 1932-1821 (print) 1932-1996 (online) DOI 10.5195/taxreview.2019.100 | http://taxreview.law.pitt.edu 
indicates when interest for specific claims should be paid. Section 1322(b)(10) suggests that for certain nondischargeable unsecured claims that arise postpetition, interest should be paid. ${ }^{150}$ The nondischargeable unsecured claims are listed in $\S 1328$. This list does not mention postpetition tax claims. ${ }^{151}$ In light of the several changes to the Bankruptcy Code, the legislature still did not include postpetition tax claims as a type of claim for which interest should be paid and not discharged. Based on Congress's awareness of this issue and Congress's choice not to codify such an exception to discharge, we can postulate that Congress intended to allow postpetition interest to be discharged.

Next, we can look at how courts interpret the text of other sections in the Bankruptcy Code, specifically $\S \S 503$ and 507, which discuss administrative and other priority taxes that may arise postpetition, to look for any indication that postpetition interest is nondischargeable. The Bankruptcy Code sets forth a priority order in which debts are paid. ${ }^{152}$ A short summary of this priority order of claims in bankruptcy begins with secured claims like mortgages and other secured assets. ${ }^{153}$ Next are priority claims such as domestic support obligations, administrative expenses such as the trustee's fees under $\S 503$, and unsecured tax claims. ${ }^{154}$ After that, nonpriority claims will be paid, such as medical bills and unsecured credit card debt. ${ }^{155}$ Finally, equity security holders' claims are paid, which is a rare occurrence. ${ }^{156}$ If any proceeds remain, the debtor is entitled to the remainder, which is even rarer.

Courts have held that interest on a tax incurred by the bankruptcy estate is payable as an administrative claim. ${ }^{157}$ The Bankruptcy Code provides that taxes are also administrative expenses under $\S 503$. Section 507(a)(2) of the

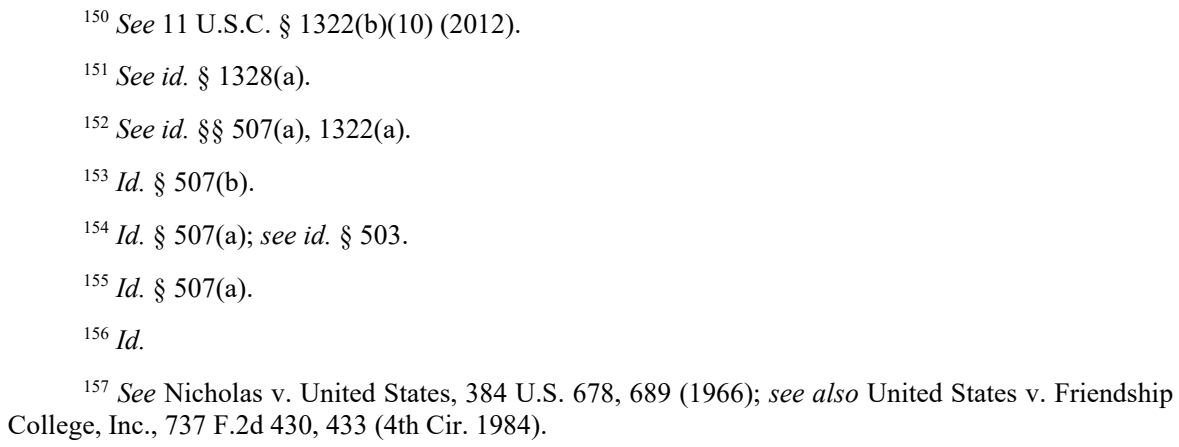

Pitt Tax Review | ISSN 1932-1821 (print) 1932-1996 (online) DOI 10.5195/taxreview.2019.100 | http://taxreview.law.pitt.edu 
Bankruptcy Code places administrative expenses high in the waterfall of bankruptcy distributions. This means that when creditors are paid in bankruptcy, these administrative claims will be one of the first claims to be paid to creditors of the debtor. However, the Bankruptcy Code does not expressly list interest as an administrative expense. ${ }^{158}$ This is significant because there is an important distinction between administrative expense tax claims and unsecured priority tax claims. In a Chapter 13 bankruptcy, the IRS cannot recover interest on prepetition unsecured priority tax claims, which is another way postpetition interest could be classified. ${ }^{159}$

Courts have held that interest on postpetition taxes can be treated as an administrative expense. ${ }^{160}$ In In re Craner, the debtor in possession incurred withholding taxes during a Chapter 11 reorganization. ${ }^{161}$ The IRS sought payment for the withholding taxes, including interest, as an administrative expense. ${ }^{162}$ The court allowed the claim with interest on two grounds. ${ }^{163}$ First, the court reviewed $\S 503$ and found that it allows for administrative expenses, including actual and "necessary costs and expenses of preserving the estate." "164 According to the court, the term " including' introduce[d] the subsections of ... $§ 503(\mathrm{~b})$ " as nonexclusive. ${ }^{165}$ Therefore, the court determined that the plain language of $\S 503$ "does not necessarily preclude the allowance of interest absent its explicit presence in the statute." 166 The court's second rationale was grounded in policy. ${ }^{167}$ The court concluded that interest on postpetition taxes should be an administrative expense in order to

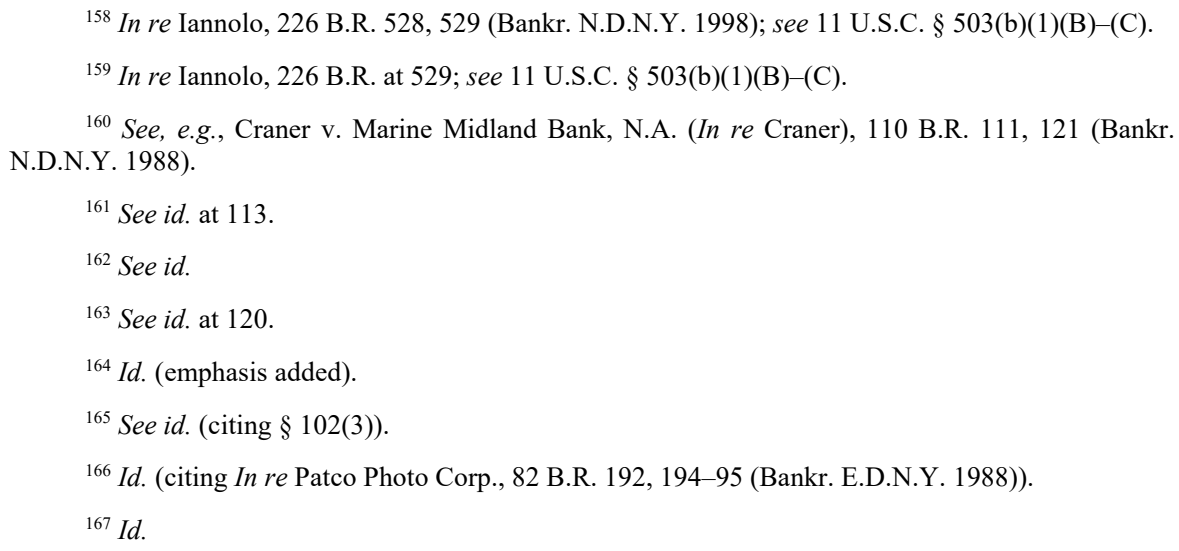

Pitt Tax Review | ISSN 1932-1821 (print) 1932-1996 (online) DOI 10.5195/taxreview.2019.100 | http://taxreview.law.pitt.edu 
avoid providing debtors with "an interest free loan at the expense of both the government and the judicial process." "168

However, there are issues with this reasoning. First, the plain language of $\S 503$ may indicate the opposite intent. Congress may have intended to preclude the allowance of interest because there is no explicit language in the statute indicating otherwise. If Congress wanted to include interest as an administrative expense, Congress could have easily included such language as it did in $\S 1322 .{ }^{169}$

Second, bankruptcy courts are generally required to deny claims for unmatured interest. ${ }^{170}$ "'[I]nterest stops accruing at the date of the filing of the [bankruptcy] petition, because any claim for unmatured interest is disallowed." $" 171$ But there are exceptions. As previously stated, Congress noted that it wanted to avoid "an interest free loan." consensual contract, usually agreed upon by the debtor and a creditor. Interest payments required by taxes are different in nature and not the same as a loan which is negotiated and agreed upon by each party. Sometimes, debts such as loans can receive interest throughout a case expressly by statute. For example, we can look to the treatment of interest with respect to secured claims.

In bankruptcy, secured creditors may receive interest when the claim is oversecured. Under the Bankruptcy Code, oversecured claims which come before priority tax claims in the bankruptcy distribution are allowed to receive interest. ${ }^{173}$ Oversecured claims are secured claims in which the debtor has equity in the asset securing the claim in an amount greater than the amount owed. ${ }^{174}$ For example, if a debtor owns a home worth $\$ 100,000$, and the payoff on his or her mortgage of the home is $\$ 80,000$, the debtor has

\footnotetext{
${ }^{168}$ Id. (citing In re Patco Photo Corp., 82 B.R. at 195).

${ }^{169} 11$ U.S.C. $\S 1322(b)(10)(2012)$.

${ }^{170}$ See id. $\S 502(b)(2)$.

${ }^{171}$ H.R. REP. NO. 95-595, at 353 (1977), as reprinted in 1978 U.S.C.C.A.N. 5963, 6309.

${ }^{172}$ See Di Vincenzo v. N.Y.C. Income Tax Bureau (In re Di Vincenzo), 1 B.R. 528, 530 (Bankr. S.D.N.Y. 1979).

${ }^{173} 11$ U.S.C. $\S 506(\mathrm{a})(1)$.

${ }^{174}$ Id.
}

Pitt Tax Review | ISSN 1932-1821 (print) 1932-1996 (online) DOI 10.5195/taxreview.2019.100 | http://taxreview.law.pitt.edu 
$\$ 20,000$ worth of equity in the home. ${ }^{175}$ Interest can be paid on an oversecured claim such as this. While an oversecured claim may receive interest, an undersecured creditor cannot. ${ }^{176}$

If a secured creditor, who has a lien on property of the debtor cannot collect interest on its claim, it seems unfair to allow a lower priority class of claims to receive interest, especially for a tax that is unsecured and the interest on which was not the result of a negotiated loan between the parties. Also keep in mind that under $\S 506$, unsecured claims do not accumulate interest, and postpetition taxes are not "loans" in the traditional sense described above. Accordingly, we should not treat postpetition taxes like loans, which would allow for interest payments, due to their distinct differences.

Finally, we look to the Bankruptcy Code's statutes relating to the discharge of debts. Within the exceptions to discharge in the current version of the Bankruptcy Code, taxes are the first type of debt mentioned. ${ }^{177}$ Interestingly, none of the exceptions to discharge in this section expressly include interest on priority tax claims. ${ }^{178}$ Again, if Congress wanted to clearly indicate that interest on postpetition taxes could not be discharged, it could have done so as part of one or more of the three major amendments to the Bankruptcy Code since Bruning.

\section{B. Looking at the Internal Revenue Code}

The Court in Bruning made the argument that Internal Revenue Code $\S 6873(a)$, which provides that "[a]ny portion of a claim for taxes allowed in ... any proceeding under the Bankruptcy Act which is unpaid shall be paid by the taxpayer upon notice and demand from the Secretary or his delegate after the termination of such proceeding," showed "no indication in [its] wording or history ... that the section was meant to limit the government's

\footnotetext{
${ }^{175}$ Usually, to receive interest, the creditor will need to prove that equity exists. But for purposes of this note, I only want to demonstrate that it is currently possible for some debts to receive interest.

${ }^{176}$ See id.

${ }^{177} I d . \S 523(\mathrm{a})(1)$.

${ }^{178}$ See id.
}

Pitt Tax Review | ISSN 1932-1821 (print) 1932-1996 (online) DOI 10.5195/taxreview.2019.100 | http://taxreview.law.pitt.edu 
right to continuing interest on an undischarged and unpaid tax liability."179 However, the Court seems to overlook the fact that within the same subchapter of the Internal Revenue Code, other sections expressly mention "interest," unlike $\S 6873$.

Section 6871, which regards claims for income, estate, gift, and certain excise taxes in receivership proceedings, expressly includes interest as part of the claim's calculation. ${ }^{180}$ Section 6871(a) and (b) include the text "together with all interest." ${ }^{\prime 181}$ Furthermore, $§ 6871(\mathrm{c})(1)$ states that "claims for the deficiency and for interest, additional amounts, and additions to the tax may be presented." 182 Congress obviously has included express language in certain statutes when it wanted to ensure interest would be included. Therefore, if Congress intended to include interest in $\S 6873$, it could have expressly included such language as it did in $\S 6871$.

In sum, both the Bankruptcy Code and the Internal Revenue Code give no clear indication whether postpetition interest should be allowed for tax claims, but they do contain clues. Since the decision in Bruning, Congress has been aware of the need for a clear statute, but it has failed to plainly indicate that interest should not be discharged. Therefore, in light of the Supreme Court's more recent decision in Kawaauhau v. Geiger, this should be taken as a signal that postpetition interest should be discharged. After looking at both the Bankruptcy and Internal Revenue Codes, both indicate that postpetition interest should be discharged. The ability to discharge postpetition interest is also supported by numerous public policy considerations.

\section{PUBLIC POLICY CONCERNS}

The Bruning decision seems to be an unnecessary limit on the debtor's fresh start. The utility of taxes must also be balanced against the debtors' interests in order to provide fairness and equal treatment to debtors. ${ }^{183}$ On the

\footnotetext{
${ }^{179}$ Bruning v. United States, 376 U.S. 358, 361 (1964).

${ }^{180}$ I.R.C. $\S 6871$.

${ }^{181} I d . \S 6781(\mathrm{a})-(\mathrm{b})$ (emphasis added).

${ }^{182} I d . \S 6781$ (c)(1) (emphasis added).

${ }^{183}$ Bruning, 376 U.S. at 361.
}

Pitt Tax Review | ISSN 1932-1821 (print) 1932-1996 (online) DOI 10.5195/taxreview.2019.100 | http://taxreview.law.pitt.edu 
one hand, courts view tax liabilities as both a priority in bankruptcy and an important public policy consideration because taxes are used to fund the government. ${ }^{184}$ On the other hand, the debtor's fresh start should be the prevailing public policy objective because of its effects on debtors.

Courts have decided against discharging postpetition interest, but what about public policy interests? The Fourth Circuit's decision in Friendship College used a report by the Senate Judiciary Committee as the sole indication that interest should be treated as part of a priority tax claim, and thus did not discharge the interest. ${ }^{185}$ However, this piece of legislative history also indicated that the interests of debtors and taxing authorities must be balanced. ${ }^{186}$ The Senate Report stated that "the goals of rehabilitating debtors and giving equal treatment to private voluntary creditors must be balanced with the interests of governmental tax authorities." 187 The Supreme Court also recognized a tension between the debtor's fresh start and discharge restrictions. ${ }^{188}$ The Court has looked for a fair balance between the fresh start and what debts are discharged. ${ }^{189}$ So far, however, the debtor's fresh start has not prevailed in this balancing effort in the courts.

Clearly, both objectives, funding the nation and giving the debtor a fresh start, affect the well-being of citizens and the country as a whole. But does allowing interest to accrue for a debtor in bankruptcy really help advance public policy? Or does it only increase the amount of harm and risk of debtors filing for a future bankruptcy, resulting in more unpaid debt to creditors such as the IRS, and take away from the debtor's fresh start? It seems to be the latter.

\footnotetext{
${ }^{184}$ See 11 U.S.C. $\S \S 503(\mathrm{~b})(1)(\mathrm{B}), 507(\mathrm{a})(8)(2012)$.

${ }^{185}$ United States v. Friendship College, Inc., 737 F.2d 430, 431 (4th Cir. 1984) (citing S. REP. No. 95-989, at 66 (1978), as reprinted in 1978 U.S.C.C.A.N. 5787, 5852).

${ }^{186}$ See S. REP. No. 95-989, at 13-14, as reprinted in 1978 U.S.C.C.A.N. at 5799-800.

${ }^{187} \mathrm{Id}$.

${ }^{188}$ Jonathon S. Byington, The Fresh Start Canon, 69 FLA. L. REV. 115, 117 (2017).

${ }^{189}$ See id.
}

Pitt Tax Review | ISSN 1932-1821 (print) 1932-1996 (online) DOI 10.5195/taxreview.2019.100 | http://taxreview.law.pitt.edu 


\section{$310 \mid$ Pittsburgh Tax Review | Vol. 162019}

The U.S. government has almost always received preferential treatment for its claims in bankruptcy. ${ }^{190}$ While there are limits on this treatment, it is still unfair to debtors who struggle to pay an entity that is itself different from any other creditor. The Bankruptcy Code was written to treat creditors fairly in bankruptcy. But, we find that Congress gave the federal government preference in bankruptcy. This seems unfair to debtors and even to other creditors. In addition, this does not give debtors a fresh start free of unnecessary debt. ${ }^{191}$

When enacting Internal Revenue Code $\S 6873$, Congress seems to have valued guaranteeing interest payments to the IRS more than a debtor's fresh start. However, this and the Bruning decision were made many years ago. Since then, bankruptcy law as a whole has changed tremendously. More importantly, every day we are learning more about the effects and persistent challenges debtors face while in bankruptcy.

If we compare a debtor's postbankruptcy finances with his or her ability to meet current bills to determine a debtor's financial health, debtors filing for bankruptcy are in very poor financial health. Most debtors do not earn an adequate income to cover even the most basic expenses ${ }^{192}$ - after all, they are in bankruptcy. After bankruptcy, most debtors hope to be in better financial health. ${ }^{193}$ Sadly, this is not always the case.

One in twelve debtors is perceived to be in worse financial shape postbankruptcy than before bankruptcy. ${ }^{194}$ Often, a debtor's postbankruptcy financial problems exceed, or are equivalent to, the financial problems that existed before the debtor sought relief. ${ }^{195}$ Debtors still struggle to meet postbankruptcy financial obligations. ${ }^{196}$ Today, nearly one in three families' financial situations either stayed the same or worsened initially

\footnotetext{
${ }^{190}$ See, e.g., Seminole Tribe v. Florida, 517 U.S. 44, 72 (1996).

${ }^{191}$ See Katherine Porter \& Deborah Thorne, The Failure of Bankruptcy's Fresh Start, 92 CORNELL L. REV. 67, 87 (2006).

${ }^{192}$ Top Ten Reasons People Go Bankrupt, supra note 39.

${ }^{193}$ A goal in bankruptcy is that the debtor should be given a fresh start from burdensome debts.

${ }^{194}$ Porter \& Thorne, supra note 191, at 88.

${ }^{195} \mathrm{Id}$.

${ }^{196}$ Id. at 90.
}

Pitt Tax Review | ISSN 1932-1821 (print) 1932-1996 (online) DOI 10.5195/taxreview.2019.100 | http://taxreview.law.pitt.edu 
postpetition. ${ }^{197}$ Plus, over a quarter of debtor families reported that their circumstances remained unchanged postbankruptcy. ${ }^{198}$ Still others reported that their financial situations worsened after bankruptcy. ${ }^{199}$ Nevertheless, courts have determined that debtors are required to pay postpetition interest in order to finance the government. ${ }^{200}$

In Bruning, the amount of interest due totaled about $\$ 795,{ }^{201}$ which is the equivalent of about $\$ 6,000$ today. ${ }^{202}$ While this number does not reflect how much every debtor would owe in postpetition interest, it does reflect that the government can collect a significant amount of interest - that compounds daily-from debtors in bankruptcy. ${ }^{203}$ In fact, if this were the amount of interest accrued during a case today, this would be over eleven percent of the median yearly income for a single debtor in Pennsylvania. ${ }^{204}$ This is a substantial amount of money the debtor must pay when the debtor is just coming out of bankruptcy. It would be unfair to require debtors to pay such a significant amount postbankruptcy, especially in a Chapter 13 bankruptcy declaration.

In a Chapter 13 bankruptcy, debtors are often required to dedicate all disposable income to the payment of creditors for three to five years. ${ }^{205}$ If a debtor were in arrears to the IRS for taxes throughout the life of a Chapter 13 plan, the debtor would accumulate interest on unpaid taxes during the entire payment period. ${ }^{206}$ This does not support the debtor's fresh start. Are there

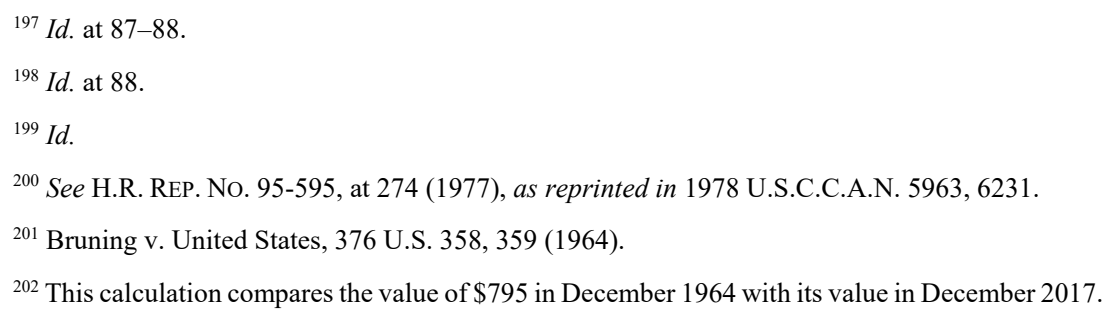
CPI Inflation Calculator, BUREAU OF LABOR STATISTICS, https://data.bls.gov/cgi-bin/cpicalc.pl (last visited Mar. 10, 2019).

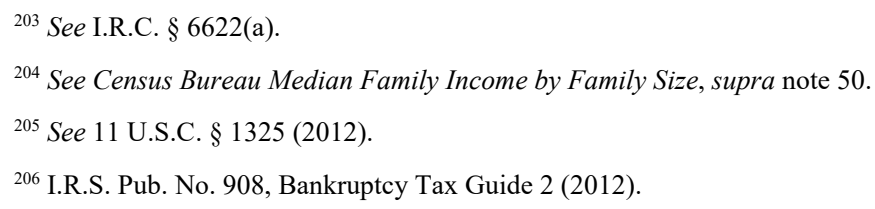

Pitt Tax Review | ISSN 1932-1821 (print) 1932-1996 (online) DOI 10.5195/taxreview.2019.100 | http://taxreview.law.pitt.edu 


\section{2 | Pittsburgh Tax Review | Vol. 162019}

other solutions? Yes, a hardship discharge may come into play to relieve the debtor, but only in rare occurrences will a debtor be able to obtain a hardship discharge. ${ }^{207}$

A hardship discharge is only available in select circumstances, and it is extremely rare to obtain. The test for a hardship discharge may also differ between jurisdictions. In the Third Circuit, the circumstances required are: (1) the debtor's failure to complete his or her plan is due to circumstances beyond the debtor's control and not the debtor's fault; (2) creditors received at least as much as they would have received in a Chapter 7 bankruptcy proceeding; and (3) it is not possible to modify the plan. ${ }^{208}$ Meeting all three requirements is very unlikely.

Even if the debtor can prove all of the elements and receive a hardship discharge, certain taxes and interest are not dischargeable. ${ }^{209}$ "[T] $[$ he income tax debt is nondischargeable under section 1328(c) of the Bankruptcy Code, [and] the IRS is entitled to collect interest and penalties that accrued postpetition against the Debtors personally." 210 If a debtor cannot pay its debts postbankruptcy or receive a hardship discharge, then there is a higher likelihood that the debtor files an additional bankruptcy. From a public policy standpoint, we should not encourage multiple bankruptcy filings by a debtor.

Debtors can even file for bankruptcy more than once over time. Recent studies found that eight percent of debtors who filed for bankruptcy filed at least once before. ${ }^{211}$ Repeat filers are responsible for about sixteen percent of all bankruptcy cases in the United States. ${ }^{212}$ It seems that debtors are not receiving a fresh start, but rather bearing the same or significantly more debt than they started with, which may lead a debtor to another bankruptcy in the

\footnotetext{
${ }^{207}$ See Chapter 13-Bankruptcy Basics, U.S. CoURTS, http://www.uscourts.gov/services-forms/ bankruptcy/bankruptcy-basics/chapter-13-bankruptcy-basics (last visited Mar. 10, 2019).

${ }^{208} I d$. 2016).

${ }^{209}$ See Interval v. Internal Revenue Serv. (In re Interval), 568 B.R. 259, 263 (Bankr. W.D. Pa.

${ }^{210} I d$.

211 Bankruptcy Statistics, DEBT.ORG, https://www.debt.org/bankruptcy/statistics/ (last visited Mar. 10, 2019).

${ }^{212} \mathrm{Id}$.
}

Pitt Tax Review | ISSN 1932-1821 (print) 1932-1996 (online) DOI 10.5195/taxreview.2019.100 | http://taxreview.law.pitt.edu 
future. ${ }^{213}$ Some of this debt may be from significant amounts of postpetition interest. Discharging this debt should help reduce repeat filings and advance public policy.

Additionally, it is unfair to think a debtor could afford to pay such debt. A major factor behind a debtor's financial struggles are "stagnant or declining income in the period following" the debtor's bankruptcy due to job and health issues. ${ }^{214}$ Many others who file for bankruptcy are not college educated or have incurred significant expenses that were unavoidable. ${ }^{215}$ In about ninety-one percent of Chapter 13 cases, bankruptcy filers identify job loss, divorce, or medical expenses as a reason for filing for bankruptcy. ${ }^{216}$ Plus, nearly half of all bankruptcy filers have faced an illness, injury, or other medical event prior to filing. ${ }^{217}$

Today, the average debtor in bankruptcy is older, only has a high school education, and makes less than $\$ 30,000$ per year. ${ }^{218}$ Taking on the amount of postpetition interest in Bruning would be nearly impossible for many debtors today. Plus, even having a bankruptcy on a debtor's credit report may very well cause families to become victims of additional unexpected hardships. ${ }^{219}$ For example, debtors may be required to pay much higher interest rates for future mortgages, car loans, and credit cards. ${ }^{220}$ With this in mind, it is hard to believe that Congress could have intended or expected for a debtor to take on, and pay off, more debt during bankruptcy.

Together, this indicates the repercussions of bankruptcy on a debtor. Researchers are discovering more about the effects of bankruptcy on debtors every day, and many debtors are not benefiting from bankruptcy as the

${ }^{213}$ It is not uncommon for debtors to file a Chapter 13 plan, wait the statutorily required time, and then file a Chapter 7 bankruptcy.

${ }^{214}$ Porter \& Thorne, supra note 191, at 117.

${ }^{215}$ James Juliano, 10 Leading Causes of Bankruptcy, SCAFIDI Juliano, LLP (Feb. 13, 2018), https://jamesjuliano.com/10-leading-causes-of-bankruptcy/.

${ }^{216}$ Chapter 13-Bankruptcy Basics, supra note 207.

${ }^{217} I d$.

${ }^{218}$ Bankruptcy Statistics, supra note 211.

${ }^{219}$ Porter \& Thorne, supra note 191, at 122.

${ }^{220}$ See Deborah Thorne, Personal Bankruptcy and the Credit Report: Conflicting Mechanisms of Social Mobility, 11 J. POVERTY 23 (2008).

Pitt Tax Review | ISSN 1932-1821 (print) 1932-1996 (online) DOI 10.5195/taxreview.2019.100 | http://taxreview.law.pitt.edu 


\section{4 | Pittsburgh Tax Review | Vol. 162019}

Bankruptcy Code intended. Postpetition interest is an unfair debt to place on debtors in bankruptcy. Congress and the courts should advance the interest of a debtor's fresh start over the government's interests. Eliminating the inability to discharge interest is one of the first steps to achieving this goal, because a debtor should not be overburdened with interest that he or she cannot pay when exiting bankruptcy.

\section{CONCLUSION}

Bankruptcy and tax are closely intertwined as demonstrated in Bruning, a case that does not lead to the results the Bankruptcy Code intended for debtors. However, due to the competing interests of the debtor's fresh start and the government's interest in raising revenue, one must give way to the other. It is hard to determine whether the impact bankruptcy has on debtors is more significant than the utility the IRS, or another taxing body, receives from accumulated interest during the debtor's bankruptcy. However, requiring interest to be paid places an unnecessary and counterproductive burden on debtors postbankruptcy. The debtor's interest in receiving a discharge that grants him or her a fresh start should prevail.

Courts should be influenced by the Bankruptcy and Internal Revenue Codes when determining if Congress's intent was to discharge postpetition interest. If this is not Congress's intent, then Congress should clearly resolve this issue by expressly stating in the Bankruptcy Code that postpetition interest is nondischargeable. In any event, public policy concerns militate strongly against codifying such an exception to discharge given that debtors already face numerous challenges in bankruptcy.

For some, interest is the time value of money. But for debtors, interest is an ever-growing and darkening cloud that hangs over their fresh start. Lawmakers should understand that postpetition interest takes away from a debtor's fresh start and causes negative consequences upon some of our nation's most vulnerable people.

Pitt Tax Review | ISSN 1932-1821 (print) 1932-1996 (online) DOI 10.5195/taxreview.2019.100 | http://taxreview.law.pitt.edu 